\title{
Penggunaan Media KIT IPA untuk Meningkatkan Kemampuan Siswa dalam Memahami Materi Gaya Magnet
}

\author{
Ngadinem \\ UPK Jatilawang Banyumas \\ Jl. Pramuka, Tunjung Wetan, Tunjung, Kec. Jatilawang, Kabupaten Banyumas, Jawa \\ Tengah \\ Email: bdmartono7@gmail.com
}

\begin{abstract}
ABSTRAK
Penelitian tindakan kelas ini memiliki latar belakang masalah yaitu rendahnya hasil belajar IPA siswa kelas V SD Negeri 5 Kedungringin tahun pelajaran 2014/2015. Penelitian ini memiliki tujuan untuk meningkatkan hasil belajar siswa pada pelajaran IPA khususnya tentang gaya magnet dan meningkatkan profesional guru sebagai tenaga pendidik. Pelaksanaan penelitian ini dilakukan melalui penggunaan KIT IPA dan pembelajaran model demonstrasi dan dilakukan dengan dua tahap, yaitu melalui siklus I dan siklus II. Setelah dilaksanakannya penelitian ini, diketahui bahwa hasil belajar siswa dalam pembelajaran IPA tentang gaya magnet semakin meningkat. Hal ini dibuktikan dengan hasil belajar IPA yang diperoleh pada pra siklus yaitu 36\% siswa telah tuntas. Setelah diberi tindakan mengalami peningkatan menjadi $68 \%$ dan di siklus II menjadi $100 \%$. Kesimpulan penelitian ini adalah dengan menggunakan KIT IPA dan pembelajaran model demonstrasi dapat meningkatkan hasil belajar IPA pada siswa kelas V khususnya tentang gaya magnet.
\end{abstract}

Kata kunci: KIT IPA dan pembelajaran model demonstrasi, hasil belajar, gaya magnet.

\begin{abstract}
This class action research has a background problem that is the low learning outcomes of science students in grade V SD Negeri 5 Kedungringin 2014/2015 school year. This study aims to improve student learning outcomes in science subjects, especially about magnetic forces and to improve the professionalism of teachers as educators. The research was carried out through the use of the Natural Science KIT and demonstration model learning and carried out in two stages, namely through cycle I and cycle II. After the implementation of this research, it is known that student learning outcomes in science learning about magnetic force is increasing. This is evidenced by the results of science learning obtained in pre-cycle that $36 \%$ of students have been completed. After being given an action it has increased to $68 \%$ and in the second cycle to $100 \%$. The conclusion of this research is that using the Natural Science KIT and demonstration model learning can improve the learning outcomes of Natural Sciences in fifth grade students especially about magnetic forces.
\end{abstract}

Keywords: Natural Science KIT and demonstration model learning, learning outcomes, magnetic force.

\section{PENDAHULUAN}

Materi gaya magnet merupakan bagian dari materi Gaya yang diajarkan pada siswa kelas V semester genap. Pada materi ini disampaikan mengenai beberapa hal antara lain gaya tarik pada magnet, kekuatan gaya magnet, kutub pada sisi magnet, kegunaan magnet 
serta cara pembuatan magnet. Pada dasarnya magnet merupakan benda yang sangat berhubungan dengan kehidupan sehari-hari siswa, misal pada beberapa alat rumah tangga, mainan bahkan asesoris. Namun pada kenyataannya nilai siswa pada materi ini rendah, hal ini dikarenakan selama ini siswa hanya menerima konsep saja tanpa dilakukan pengamatan secara langsung, sehingga hal ini menyebabkan siswa hanya dapat menghafal dan membayangkan saja konsep-konsep mengenai magnet sesuai yang diajarkan oleh guru. Siswa memperoleh pengetahuan hanya melalui penjelasan yang diberikan oleh guru, siswa tidak mengalami sendiri proses belajar yang akan membuat siswa memperoleh pengalaman belajar sendiri. Hal ini yang menyebabkan pembelajaran tidak bermakna sehingga ingatan siswa pada materi ini rendah atau tidak bertahan lama. Untuk dapat membuat ingatan siswa tertanam lebih lama maka diperlukan suatu solusi yang tepat, salah satunya adalah dengan menggunakan media pembelajaran yang tepat.

Kit IPA merupakan alat-alat yang digunakan untuk percobaan dalam pembelajaran IPA di kelas Sekolah Dasar (Trisnoherawati, 2004). Dengan menggunakan kit siswa dapat mengalami pembelajaran sendiri dengan cara pengamatan dan percobaan. Dengan kit terutama yang berhubungan dengan materi gaya magnet siswa dapat mengetahui jenis-jenis magnet, mekanisme gaya tarik magnet, mempraktikkan cara membuat magnet dan lainlain. Dengan menggunakan kit tersebut siswa memperoleh konsep dari pengalamannya selama proses pengamatan dan pelaksanaan percobaan. Proses pembelajaran akan terasa bermakna bagi siswa, sehingga ingatan siswa terhadap materi akan tertanam lebih lama dalam pikiran siswa. Beberapa kajian teori dalam penelitian ini sebagaimana dipaparkan dalam uraian berikut.

Kit IPA merupakan alat-alat yang digunakan untuk percobaan dalam pembelajaran IPA di kelas Sekolah Dasar (Trisnoherawati, 2004). Secara umum Kit IPA merupakan alat peraga yang digunakan dalam membuktikan teori-teori IPA yang dihubungkan dengan lingkungan alam yang tujuannya mendorong anak agar mampu mengembangkan potensi yang dimilikinya. Berdasarkan hal tersebut, maka Kit IPA perlu digunakan agar dapat membantu dan memudahkan siswa memahami konsep pesawat sederhana sehingga pembelajaran menjadi aktif, menarik, komunikatif, bermakna dan tidak menjenuhkan. Secara etimologi IPA atau Sains berasal dari bahasa latin, yaitu Scientia yang secara sederhana berarti pengetahuan atau knowledge (Fsicher, 1975). Sains diartikan sebagai pengetahuan yang secara sistematis tersusun (assembled) dan bersama-sama dalam suatu urutan terorganisasi. Dari pendapat beberapa ahli sebelumnya dapat ditarik pengertian secara umum bahwa Sains adalah ilmu pengetahuan atau kumpulan konsep, prinsip, 
hukum dan teori yang dibentuk melalui proses kreatif yang sisrematis melalui inkuiri yang dilanjutkan dengan proses observasi (empiris) secara terus menerus; merupakan suatu upata manusia yang meliputi operasi mental, keterampilan dan strategi manipulasi dan menghitung, yang dapat diuji kembali kebenarannya yang dilandsi dengan sikap keinginan (curiousity), keteguhan hati (courage) dan ketekunan (persistence) yang dilakukan oleh individu untuk menyingkap rahasia alam semesta (Mariana \& Praginda, 2009). Untuk melakukan proses sains atau IPA perlu dilakukan suatu metode yan disebut dengan metode ilmiah atau scientific method. Metode ilmiah memiliki beberapa langkah-langkah kegiatan, antara lain

1) Perumusan masalah

2) Penyusunan kerangka berfikir dalam mengajukan hipotesis

3) Perumusan hipotesis

4) Pengujian hipotesis

5) Penarikan kesimpulan.

Hasil belajar menurut Dimyati dan Moedjiono dalam Ketut Jelantik (2009) mengemukakan bahwa "Hasil belajar merupakan hasil dari suatu interaksi tindak mengajar atau tindak belajar". Menurut Sadiman (2008:6) dalam Tarmizi, 2009 (http//id.tarmizi wordpress.com) menyatakan bahwa : Hasil belajar sebagai suatu keluaran dalam proses belajar. Pertanda bahwa seseorang telah belajar adanya perubahan tingkah laku dalam dirinya. Perubahan tingkah laku tersebut menyangkut baik perubahan yang bersifat pengetahuan atau kognitif, ketrampilan atau psikomotorik maupun yang menyangkut nilai dan sikap atau afektif. Dari kutipan-kutipan di atas dapat diambil kesimpulan pengertian hasil belajar adalah akibat yang menunjukkan perubahan dari sebelum menerima pengalaman belajar dengan setelah menerima pengalaman belajar yang ditunjukkan dengan perubahan, peningkatan, dan penyempurnaan tingkah laku sebagai hasil latihan dan pengalaman.

\section{METODE PENELITIAN}

Perbaikan pelaksanaan pembelajaran pada materi Gaya Magnet dilaksanakan pada kelas V semester II (dua) tahun pelajaran 2014/2015 yang bertempat di SDN 5 Kedungringin, UPK Purwojati, Kabupaten Banyumas. Jumlah siswa keseluruhan adalah 21 orang siswa, yang terbagi atas 9 siswa laki-laki dan 12 siswa perempuan. Penelitian dilaksanakan pada semester 2, tahun pelajaran 2014/2015. Berikut adalah jadwal lengkap pelaksanaan tindakan kelas yang dulaksanakan di SD Negeri 5 Kedungringin. Penelitian 
dilakukan dalam dua siklus, langkah - langkah penelitian terdiri dari empat tahap yaitu : perencanaan (planning), tindakan (acting), pengamatan (observing), dan refleksi (reflecting) (Wardani, 2006:24). Sedangkan menurut Susilo H (2002:22) mengatakan bahwa dalam penelitian tindakan kelas ada beberapa langkah-langkah yang harus diikuti oleh peneliti yaitu : perencanaan, implementasi tindakan, observasi, dan refleksi. Dalam prosedur penelitian tergambar peran tim peneliti dalam setiap tahapan penelitian. Data yang diperlukan dalam penelitian ini ada dua macam yaitu data primer dan data skunder. Data primer terdiri dari angket dan observasi. Data sekunder berisi nilai yang diperoleh dari tes hasil belajar Pendidikan Kewarganegaraan materi sub pokok bahasan lembaga pemerintahan desa dan pemerintah kecamatan pada semester I dengan setiap akhir siklus diadakan tes. Data yang dikumpulkan adalah data kuantitatif dan data kualitatif yang terdiri atas :
a. Hasil Nilai Evaluasi (Data Kuantitatif)
b. Lembar Observasi (Data Kualitatif)

Teknik pengumpulan data yang dilakukan peneliti melalui tes dan non tes. Melalui tes berupa tes tertulis yang dilakukan pada akhir siklus I dan siklus II. Melalui non tes berupa pengamatan yang dilakukan teman sejawat/kolaborator. Alat pengumpul data tes berupa perangkat tes soal evaluasi akhir siklus I dan siklus II. Sedangkan alat pengumpul data non tes berupa lembar observasi siswa yang diisi dengan bantuan teman sejawat/kolaborator.

\section{HASIL DAN PEMBAHASAN}

\section{Siklus I}

Berdasarkan hasil dari pelaksanaan perbaikan pembelajaran pada siklus I diperoleh data bahwa minat belajar siswa mengalami peningkatan jika dibandingkan dengan pembelajaran pra siklus. Hal ini dibuktikan dengan jumlah siswa yang dikategorikan minat adalah sejumlah 14 siswa atau 67\% dan siswa yang belum minat sejumlah 7 siswa atau 33\%. Hasil belajar siswa yang diraih pada siklus ini juga mengalami peningkatan yaitu siswa yang tuntas sejumlah 14 siswa atau $67 \%$ dan siswa yang belum tuntas sejumlah 7 siswa atau 33\%.mAdapun peningkatan minat belajar siswa pada pra siklus dan siklus 1 dapat dilihat pada gambar 1 dibawah ini: 


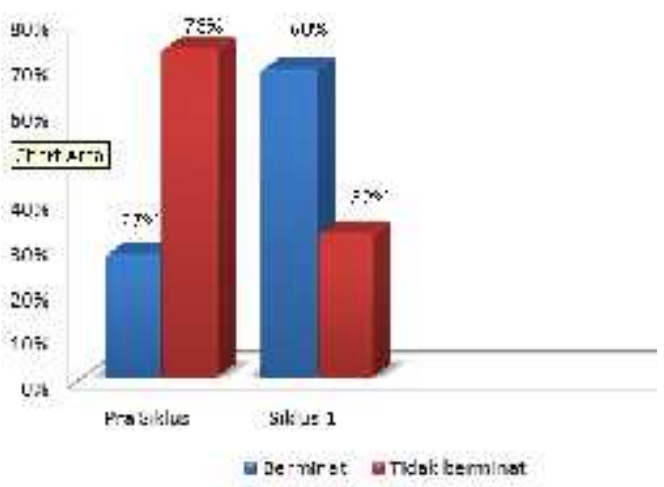

Minat dan hasil belajar siswa pada siklus I sudah cukup ada peningkatan walaupun belum secara maksimal. Pembelajaran menggunakan KIT IPA pada mata pelajaran IPA tentang gaya magnet sudah cukup berdampak positif. Hal ini disebabkan karena siswa dapat berinteraksi langsung dengan alat peraga dalam KIT IPA dan setiap siswa dapat mempraktekan secara koinkret.

\section{Siklus I}

Setelah dilaksanakannya perbaikan pembelajaran pada siklus II ternyata dapat diperoleh hasil yang cukup memuaskan baik dari minat belajar ataupun hasil belajar siswa. Hal ini dibuktikan dengan jumlah siswa yang berminat dalam belajar adalah sejumlah 21 siswa atau $100 \%$ dan yang tidak berminat dalam belajar adalah 0 siswa atau $0 \%$. Hasil belajar siswa juga mengalami peningkatan secara maksinal yaitu siswa yang sudah tuntas dalam belajar adalah sejumlah 21 siswa $100 \%$ dan yang belum tuntas adalah 0 siswa atau $0 \%$. Penggunaan media KIT IPA yang tepat pada mata pelajaran IPA tentang gaya magnet telah membuat siswa semakin berminat, aktif dan kreatif dalam mengikuti pelaksanaan pembelajaran. Adapun peningkatan minat belajar siswa pada siklus I dan siklus II dapat dilihat pada Gambar 4.3 dibawah ini.

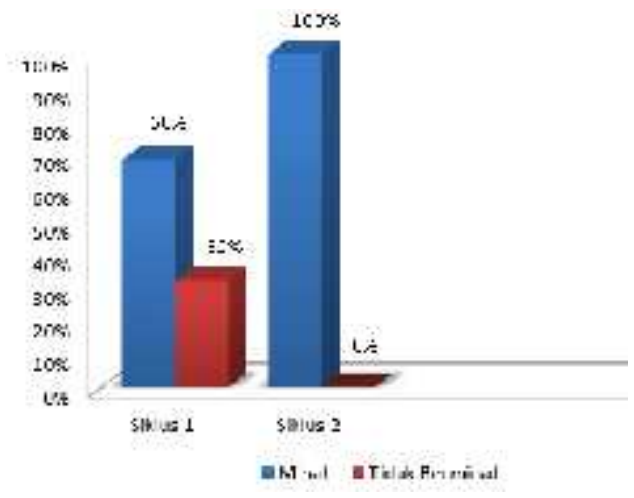


Melalui pelaksanaan perbaikan pembelajaran IPA tentang gaya magnet menggunakan media KIT IPA bagi siswa kelas V SD Negeri 5 Kedungringin yang dilakukan selama dua siklus terbukti dapat meningkatkan hasil belajar siswa dengan sangat baik. Selain itu perbaikan pembelajaran yang telah dilaksanakan juga telah membuat siswa mempunyai semangat belajar yang tinggi, aktif dan lebih mudah dalam memahami materi yang disampaikan. Berdasarkan data hasil belajar yang diperoleh siswa dalam setiap siklusnya dan dari pengamatan aktivitas siswa selama proses pembelajaran perbaikan pembelajaran IPA tentang gaya magnet menggunakan media KIT IPA bagi siswa kelas V SD Negeri 5 Kedungringin UPK Purwojati dinyatakan telah berhasil terbukti dari ketuntasan hasil belajar siswa pada siklus II telah mencapai $100 \%$.

\section{KESIMPULAN}

Berdasarkan hasil penelitian yang telah dilaksanakan dapat disimpulkan sebagai berikut.

1. Penggunaan media kit dalam pembelajaran IPA materi gaya magnet dapat meningkatkan aktivitas belajar siswa

2. Penggunaan media kit dalam pembelajaran IPA materi gaya magnet dapat meningkatkan hasil belajar siswa, hal ini dibuktikan dengan peningkatan jumlah siswa yang tuntas belajar yaitu :

siklus I : Terdapat 14 siswa yang mencapai KKM

siklus II : Semua siswa dapat mencapai KKM yang ditetapkan (nilai 70).

3. Penggunaan media kit dapat meningkatkan pemahaman siswa terhadap materi gaya magnet mata pelajaran IPA.

\section{SARAN}

Perlu diekspolari dan dikembangkan berbagai media pembelajaran khususnya mata pelajaran IPA

\section{DAFTAR PUSTAKA}

Ahmad. (1997). Pedoman Penggunaan Kit IPA di Sekolah Dasar. Jakarta: Depdikbud.

Arshad, Azhar. ( 2009). Media Pembelajaran. Jakarta: Rajawali Pers.

Depdiknas. (2003). Media Pembelajaran. Jakarta: Depdiknas.

Depdiknas, (2007). Standar Proses. Jakarta : Depdiknas. 
Fsicher R. (1975). Science, Man and Society. Toronto: W. B Saunders Company.

Mariana I \& Praginda W. ( 2009). Hakikat IPA dan Pendidikan IPA. Jakarta: Pusat pengembangan dan Pemberdayaan pendidikan dan Tenaga Kependidikan Ilmu Pegetahuan Alam (PPPPTK IPA).

Sadiman, Arif. (2008). Media Pendidikan. Jakarta: PT Raja Grafindo Persada.

Sardiman. (2007). Interaksi dan Motivasi Belajar Mengajar. Jakarta: PT Raja Grafindo Persada.

Siahaan P dan Suyana I. (2010). Hakekat Sains dan pembelajarannya. Bandung: UPI press.

Siahaan S. (2006). Media Pembelajaran: Mitra atau kompetitor bagi Guru dalam kegiatan Pembelajaran? Jurnal pendidikan dan Kebudayaan 12 (63) : 793-811.

Sudjana N \& Rivai A. (2005). Media Pengajaran. Bandung: Sinar Baru Algensindo.

Septiana N. 2008. Media belajar dari sudut pandang psikologi pembelajaran. Jurnal Pendidikan Inovatif 3 (1): 24-30. On line at http://jurnaljpi.wordpress.com/2008/01/25/nenny-septiana/ [diakses tanggal 25 Juni (2009)

Trisnoherawati N. 2004. Pengaruh Kit IPA Terhadap Prestasi Belajar Siswa.[Google] tersedia: http://www.damandiri.or.id/file/naniktunpabs bab II Pdf ( 10 Januari 2010). 